\title{
STRUCTURAL CHANGES IN THE INDUSTRY OF POLAND AGAINST THE BACKGROUND OF EASTERN EUROPEAN UNION STATES
}

\author{
WiESEAWA GIERAŃCZYK \\ Torun Higher School, Torun, Poland \\ TOMASZ RACHWAE \\ Institute of Geography, Pedagogical University of Cracow, Cracow, Poland \\ Manuscript received: December 14, 2011 \\ Revised version: March 6, 2012
}

\begin{abstract}
GIERAŃCZYK W., RACHWAE T., Structural changes in the industry of Poland against the background of eastern European Union states. Quaestiones Geographicae 31(2), Bogucki Wydawnictwo Naukowe, Poznań 2012, pp. 83-93. 1 table, 6 figs. DOI 10.2478/v10117-012-0021-9, ISSN 0137-477X.

АвSTRACT. Industrial restructuring processes associated with the transformation of the system taking place in Poland and other countries of Central and Eastern Europe bring about structural changes in manufacturing intended to develop intellectually-intensive industries based on the implementation of the latest research and development $(R \& D)$ results. The purpose of this article is therefore to present changes in the role of industry in the economy of Poland based on its share in employment and gross value added in comparison with other eastern EU countries, as well as structural changes in the industrial sectors (NACE divisions). The comparison will assess the competitive position of Polish industry on international markets, particularly against the other states transforming their economies. The analysis will seek to establish to what extent the structural changes in Polish industry indicate positive effects of the country's economic transformation.
\end{abstract}

KEY WORDS: European Union, industry, Poland, restructuring processes, structural changes

Tomasz Rachwat, Institute of Geography, Pedagogical University of Cracow, ul. Podchorążych 2, 30-084 Kraków, Poland; e-mail: T.Rachwal@up.krakow.pl (corresponding author)

Wiestawa Gierańczyk, Toruń Higher School, ul. Młodzieżowa 29, 87-100 Toruń, Poland; e-mail: w.gieranczyk@tsw.edu.pl

\section{Introduction}

The restructuring process of the industry of Poland and other Central and East European countries connected with their transition from a centrally planned to a market economy should be moving towards the development of intellectually-intensive industries, i.e. those based on knowledge. According to Thurow (1996), the economic success of a state depends on its progress on the way towards knowledge-intensive sectors. The skill to use knowledge and information is the basis for building innovativeness, which means the ability of entities and economies to create and implement innovations, undertake activities stimulating innovativeness, and engage the necessary resources (Gierańczyk 2009a). A measurable effect of knowledge transformed into direct manufacturing power is the appearance of high-tech sectors, which operate at the crossroads of science 
and industry and process the results of scientific research. They are characterised by a short life cycle of their goods and processes, fast diffusion of technological innovations, increasing demand for highly qualified labour force, large capital inputs, high investment risk, and rapid 'ageing' of investment (Nauka ... 2007). The share of hightech industry in employment and value added, as indicated by many authors (Chojnicki \& Czyż 2006, Czyż 2010, Gurbała 2010, Stachowiak 2009, Stryjakiewicz 2002, Świdurska 2010), is one of the factors boosting the competitiveness of regions and the socio-economic development of countries. From this perspective it seems important to examine how the processes of industrial restructuring in Poland and other European countries undergoing economic transformation have helped them to improve their competitiveness on international markets.

This paper aims to present structural changes in Poland's industry as a sign of restructuring of its entire economy against the backcloth of other EU states, especially those from Central and Eastern Europe (CEE). The analysis will seek to establish to what extent the structural changes in Polish industry involving an increasing share of the high-tech sector in employment and production value are indicative of positive effects of the economic transformation. The modernity of industry is considered against the general economic change taking place in Poland and the other CEE states at the time of their systemic transformation and involving a change of the role of industry in the economy in terms of its share in the employment structure and gross value added, as well as structural changes in the industrial sectors (the NACE division).

The sources of statistical data were the yearbooks of the Polish Central Statistical Office (Główny Urząd Statystyczny - GUS) and the Eurostat database. It must be noted, however, that in the case of a few states there were difficulties in obtaining comparable data, which made it necessary to adopt various time spans for analysis. The issue of serious difficulties in obtaining detailed statistical data on the development of industry for given time spans has already been discussed in numerous publications (e.g. Rachwał 2008).

The analysis also includes the results of earlier studies on innovativeness and competitiveness of the industry of Poland and other European states (Gierańczyk 2003, 2008, 2009a, b, 2010a, b; Stańczyk 2003), the branch structure of Polish industry (Rachwał 2010, 2011a), spatial differences in industry in the various EU regional systems (Rachwał, Wiedermann \& Kilar 2008, 2009) as well as changes in Polish industry against the backcloth of other European countries (e.g. Domański 2003, 2006; Rachwał 2009, 2011b; Stryjakiewicz 1999, 2002). The paper, however, presents only the most important results of the above studies.

\section{The changing role of industry in the economy}

Contemporary changes in the world economy connected with the transition from the industrial via the post-industrial to an information-based phase of civilisational development resulting from globalisation processes, alter the sectoral structure of the economy. The place of industrial activity, which used to be the economic foundation of the industrial stage, is being taken by services, especially those connected with science and education that become the basic building element of a knowledge-based economy. A consequence is a change in the role of industry in the economic development of various spatial systems, an issue which has been of interest to many authors (e.g. Rachwał, Wiedermann \& Kilar 2009; Zioło 2008, 2009).

That the importance of industry is changing in the economies of Poland and other eastern EU states (also going though restructuring processes) finds support in the data, which indicate that the share of industry in employment and gross value added tends to change (Fig. 1). Although not in all the states, this share is generally diminishing; in the case of employment, this is mainly due to the mechanisation, automation and computerisation of production processes and, as a result, the elimination of human work from industry. Another factor is a systematic increase in labour productivity, which is not only connected with investment in new production technologies, but also with the implementation of new rules of labour organisation and management. This is mainly visible in firms included into the structures of international corporations, which 

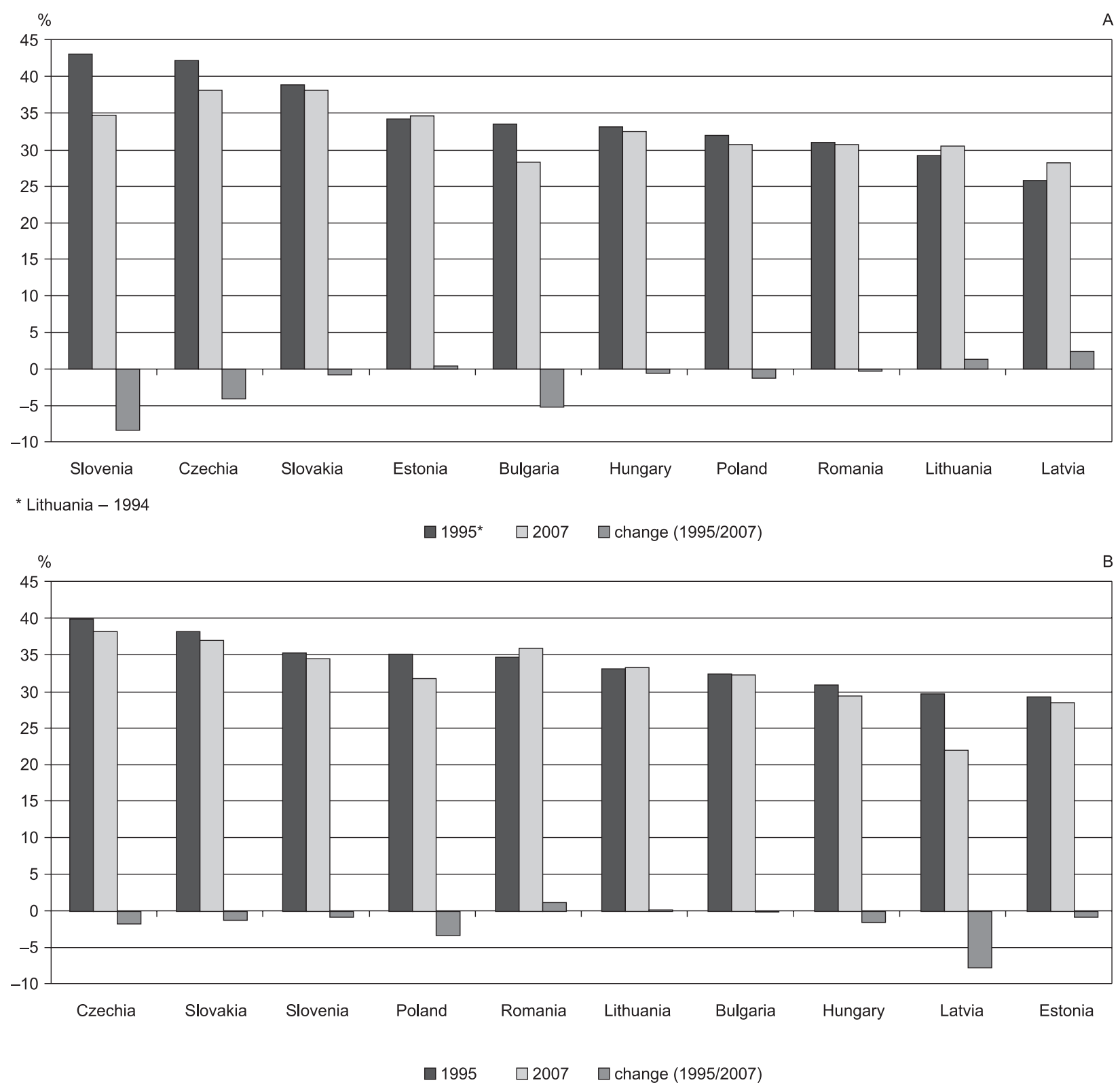

Fig. 1. Share of industry and the construction sector in employment (A) and gross value added (B) in Poland and other eastern EU states in 1995-2007.

Source: compiled by the authors on the basis of GUS data.

has been corroborated by numerous studies of the restructuring processes of industrial plants in Poland (e.g. Domański 2001; Rachwał 2006a, b; Tobolska 2006a, b).

The differences between the shares of industry in employment and gross value added in the analysed periods indicate that although in most countries this share decreased (by a few percentage points), which is consistent with the trends in the whole of Europe, in some of them it declined only slightly, or even increased. In consequence, if compared with the West European states, the share of this sector is still relatively high, especially in Czechia and Slovakia, where it reaches almost $40 \%$.

On the one hand, this shows the persistence of the industrial structures shaped under the former central planning system. On the other, however, in the late 1990s and early 2000s the transformation processes brought numerous new investments in the industries of the CEE states, which involved creating new jobs and an increase in the gross value added produced by industry. A good example is investment in the car industry 
in many industrial regions of CEE states, including Poland's Silesian voivodeship, which was analysed in detail by Wiedermann (2007; see also Rachwał \& Wiedermann 2008). Another indication is annual statistical data for Poland which show a change in the shares of its industry and construction in employment and gross value added, with a significant decrease recorded in 1995-2001 followed by an increase in 2002-2007. The increase also resulted from the dynamic development of export production stimulated by the favourable economic situation of those years as well as the accession of the analysed states to the European Union.

The dynamic development of export of industries of CEE states was possible thanks to changes introduced into the technological process which enabled the production of more advanced goods. At the end of the central planning period, their industrial enterprises had highly depreciated fixed assets which did not enable them to manufacture competitive products in the new conditions of a market economy. Deep technological changes were only possible in those firms which had sources of financing the modernising process. As the earlier studies found (e.g. Domański 2001, 2003, 2006; Rachwał 2006a, b; Stryjakiewicz 2004; Tobolska 2007, 2010; Zalesko 2008), the leading role was played here by foreign capital. When analysing its role in the changes in industry, one must agree with the conclusion drawn by Domański (2001) that on the whole the balance of the effects of the foreign capital inflow to Poland and other CEE states has been favourable. Foreign investment increases the competitiveness of both CEE firms and entire economies by introducing modern technologies and organisation of production which, in turn, raises their effectiveness and triggers off positive structural changes.

\section{The sectoral structure of industry}

Another indicator of transformation processes is changes in the sectoral structure of industry. The analysis of this structure for Poland was based on the PKD 2004 (NACE 1.1) sections and divisions, which was in force until the end of 2007. It was carried out in terms of industrial employment and the value of industrial production sold as well as a synthetic indicator calculated from them (Zioło 1972, 1973) which made it possible to synthesize those two empirical measures. The advantage of using a synthetic indicator is that its value is influenced by both, the number of workers, which is significant in labour-intensive sectors, and the value of production sold, crucial for more technologically advanced industries with their high R\&D expenditure. As presently industry is no longer the leader in activating labour resources, it would seem inappropriate to rely on only one commonly used indicator - that of employment. This approach would give prominence to the labour-intensive sectors of the economy, while underestimating modern industries with their highly mechanised and automated production process and high value added.

When analysing data on changes in the structure of employment in industry by section and division, it was found that industrial employment in Poland decreased by about $13 \%$ over the study period, while the value of production sold (at current prices) grew almost fourfold. However, with almost $90 \%$ of the share in industrial employment and production sold taken by section D (Manufacturing), an analysis of differences in those variables by section does not allow conclusions as to changes in the branch structure of Polish industry. Thus, in order to see structural changes in industry, it is necessary to conduct the analysis at the level of divisions. The largest figures for employment and the value of production sold are recorded in the divisions 'Manufacture of food products and beverages', 'Manufacture of machinery and equipment' and, especially recently, 'Manufacture of metal products'. A relatively important role is also played by mining, in the analysis including all the four divisions of section C Mining, since over $90 \%$ of its workforce potential is accounted for by coal mining.

Modern manufacturing divisions (DL30 to DL33) show relatively low employment potential and small gross value added. Changes in the size of employment and the value of production sold in the individual divisions are reflected in changes in the branch structure. One can observe manufacture of food as well as of machinery and equipment to have kept their relatively high shares, but there is a significant decline in the importance of mining, which lost its second 

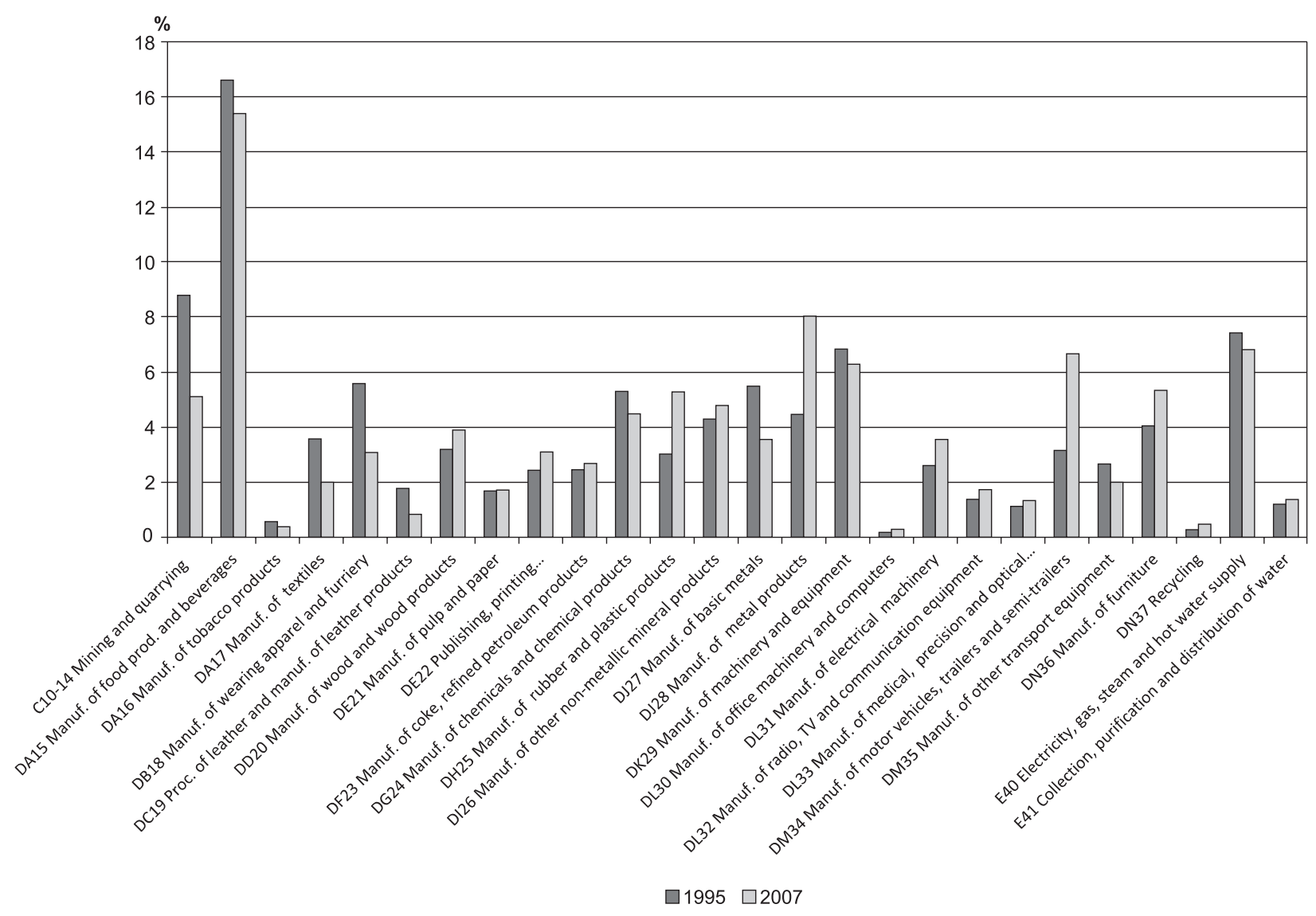

Fig. 2. Division structure of Poland's industry in 1995 and 2007 based on the synthetic indicator.

Source: compiled by the authors on the basis of GUS data.

position in the 1995 ranking to other branches (Fig. 2).

As the analysis of changes in the share of the individual divisions in the structure of both employment and the value of production sold indicates, the most traditional labour-intensive branches, such as mining, manufacture of wearing apparel, textiles and leather products, but also machinery and equipment, power production and chemical industry, lost in importance over the study period (Fig. 3). The divisions which significantly increased their share include manufacture of metal, rubber and plastic products, furniture, and vehicles. Not all of them can be treated as the most technologically advanced. It seems that in those specific cases the increase was due to substantial foreign investment, which boosted their share in the structure.

However, an interesting research issue would be to find how the changes in the branch structure of Polish industry compare with changes in the other EU states, including those transforming their economies. In the light of a research in this area employing cluster analysis (Rachwał 2010, 2011), it is clear that the transformation of the structure of Polish industry over the years 1995-2007 aimed at making it conformable with that of the highly developed western EU countries, such as France or the United Kingdom. It meant a great change from the mid-1990s when the structure of Polish industry was similar to that in other CEE countries. From the point of view of the restructuring goals, this transformation should be assessed as a highly favourable development.

\section{Development of the high-tech sector}

An active policy of innovativeness, creativity and development of industrial firms is visible through structural changes in production which show its greater ability to produce new and modern goods. Branches which might be called 'modern' have existed at every stage of economic development. Modernity stems from a given in- 


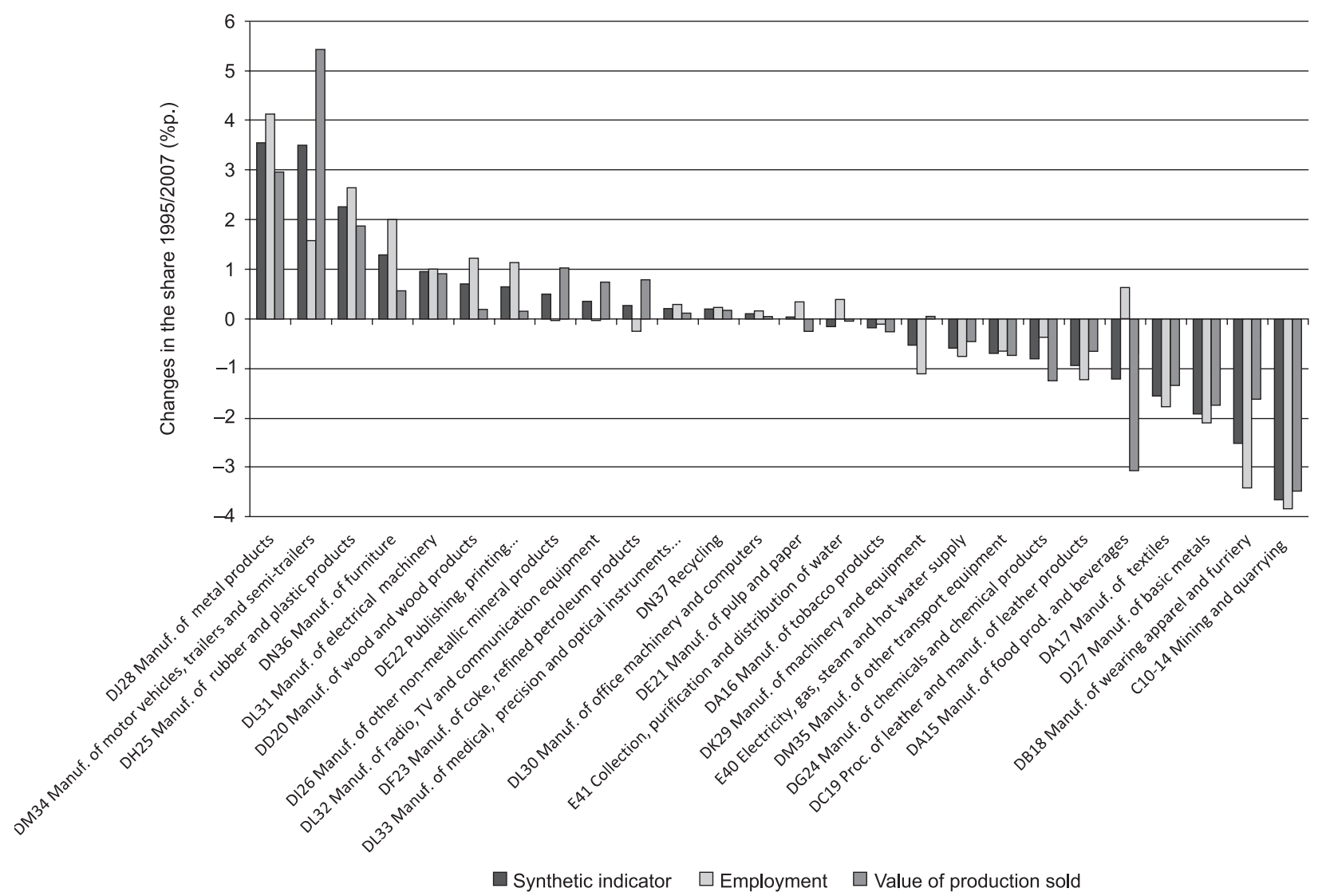

Fig. 3. Changes in the share of individual divisions in the structure of Poland's industry in 1995-2007 Source: compiled by the authors on the basis of GUS data.

dustry using technological processes and solutions to manufacture its products.

The idea of high-technology (high-tech, HT) industries first appeared in specialised literature in the mid-1960s with the rapid development of modern - by the then standards - manufacturing branches (Wiśniewska 2002). Generally, this category includes branches which operate at the crossroads of science and industry and implement the results of scientific research. At present,

Table 1. High-tech industries according to NACE Rev. 1.1.

\begin{tabular}{|c|c|}
\hline Codes & Manufacturing high-technology industries \\
\hline 24.4 & $\begin{array}{c}\text { Manufacture of pharmaceuticals, medicinal } \\
\text { chemicals and botanical products }\end{array}$ \\
\hline 30.0 & $\begin{array}{c}\text { Manufacture of office machinery and com- } \\
\text { puters }\end{array}$ \\
\hline 32.0 & $\begin{array}{c}\text { Manufacture of radio, television and com- } \\
\text { munication equipment and apparatus }\end{array}$ \\
\hline 33.0 & $\begin{array}{c}\text { Manufacture of medical, precision and opti- } \\
\text { cal instruments, watches and clocks }\end{array}$ \\
\hline 35.3 & Manufacture of aircraft and spacecraft \\
\hline
\end{tabular}

Source: NACE (Nomenclature Statistique des Activités Économiques dans la Communauté Européenne) Rev. 1.1. the EU nomenclature delimits the high-tech sector on the basis of the OECD methodology developed for the years 1980-1995 by division. Table 1 presents these high-tech branches in accordance with this classification.

Today the ability of an economy to move to a higher level of technology and, consequently, to produce better economic, social and ecological effects, is a key factor determining its ability to achieve long-term, effective growth (Fic 2004). Therefore, the level of development of its hightech sector is considered one of the basic indicators of the modernity and competitiveness of the economy.

According to earlier studies (Gierańczyk 2010a, b, Turowski 2005), the highest and constantly growing share of high-tech goods in industrial output is a mark of the best developed states of the world, such as Japan (about 16\%), the USA (about 21\%) and South Korea (19\%). Although in Poland the number of high-tech firms increased from 600-800 in 2000 (Rot \& Brodzicki 2001) to over 2,000 in 2007 (Świdurska 2009), the 
proportion of high-tech production in the total value of industrial output declined and was one of the lowest among the eastern EU member states (Fig. 4). This means that the technological gap between Poland and the leaders of innovativeness is widening. Apart from this gap in which Poland lags more than five years behind the world leaders of innovativeness, other indications of this fact, according to Grudzewski \& Hejduk (2008), include:

- weaker competitiveness of many Polish products on the world markets,

- a marked competitive advantage of foreign products, which often come from countries of at most a medium level of development,

- lower productivity of many foreign technologies used in Polish industry,

- overuse of materials, resources and energy, and

- too wide a range of products manufactured by one company, which limits its specialisation and ability to reduce unit costs.

While similar tendencies could be observed in the development of the high-tech sector in Poland in terms of the value added structure too, there are symptoms of its industrial structures getting modernised. From the point of view of economic growth, it is not only high-tech production which is crucial, but also the use of modern technologies to manufacture goods at a lower level of technological advancement. Considering the fact that over the study period Poland recorded a 5\% growth in the share of the sector of medium technology at the expense of low technology, there seems to be a tendency for the quality and reli-

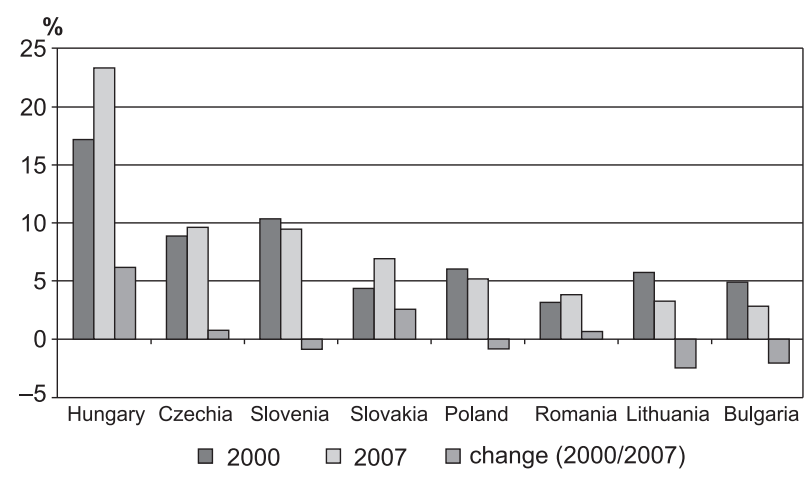

Fig. 4. Share of the high-tech sector in the production structure of Poland and other eastern EU states in 2000-2007. Source: compiled by the authors on the basis of Eurostat data. ability of products to improve, which indicates a better use of capital resources.

At the same time it can be observed that the growth dynamics of the production of high-tech goods in Poland was lower than in the other sectors of industry. This means that modernisation is being achieved by an increase in the production of those goods which show a greater technological lag than high-tech ones. This tendency is proved by a higher share in the value of sales of products which are new only to the given companies (Fig. 5). New items put on the market by Polish firms for the first time are rather rare and, as the research reveals, this is mainly done by the companies with the participation of foreign capital. Good examples of such practices are the factories Isuzu in Tychy and Volkswagen in Polkowice Dolne which produce the latest models of Diesel engines. The company Alstom Power Generators (previously ABB Domel) in Wrocław specialises in creating unique prototypical generators. In Piła Philips has introduced mass production of the most modern sources of light. Other most advanced companies include pharmaceutical firms with foreign investors, which are a match for West European firms in terms of technology and culture of production, e.g. Pliva Kraków, which together with Pfizer has patented a modern antibiotic. In 2008 the share of new products on the export markets was insignificant, at less than $2 \%$. Examples of companies producing for the European or global markets include ABB Elta of Łódź, which has the status of a European concern producing distribution transformers, ABB Zwar of Warsaw, which produces capacitor voltage transformers, SKF of Poznan, which is the producer of some assortment of cylindrical and conical bearings, and Philips of Kwidzyń, which produces television heads (Zalesko 2008).

In the study period, changes in the high-tech share in the structure of production value and value added differed from those in the structure of employment. Although there was a general tendency for industrial employment to decrease, the number of those working in the high-tech sector actually increased, while those employed in the low-tech sector dwindled significantly. This means that the sectors of lower technological advancement recorded a decrease in employment following improved labour efficiency due to 


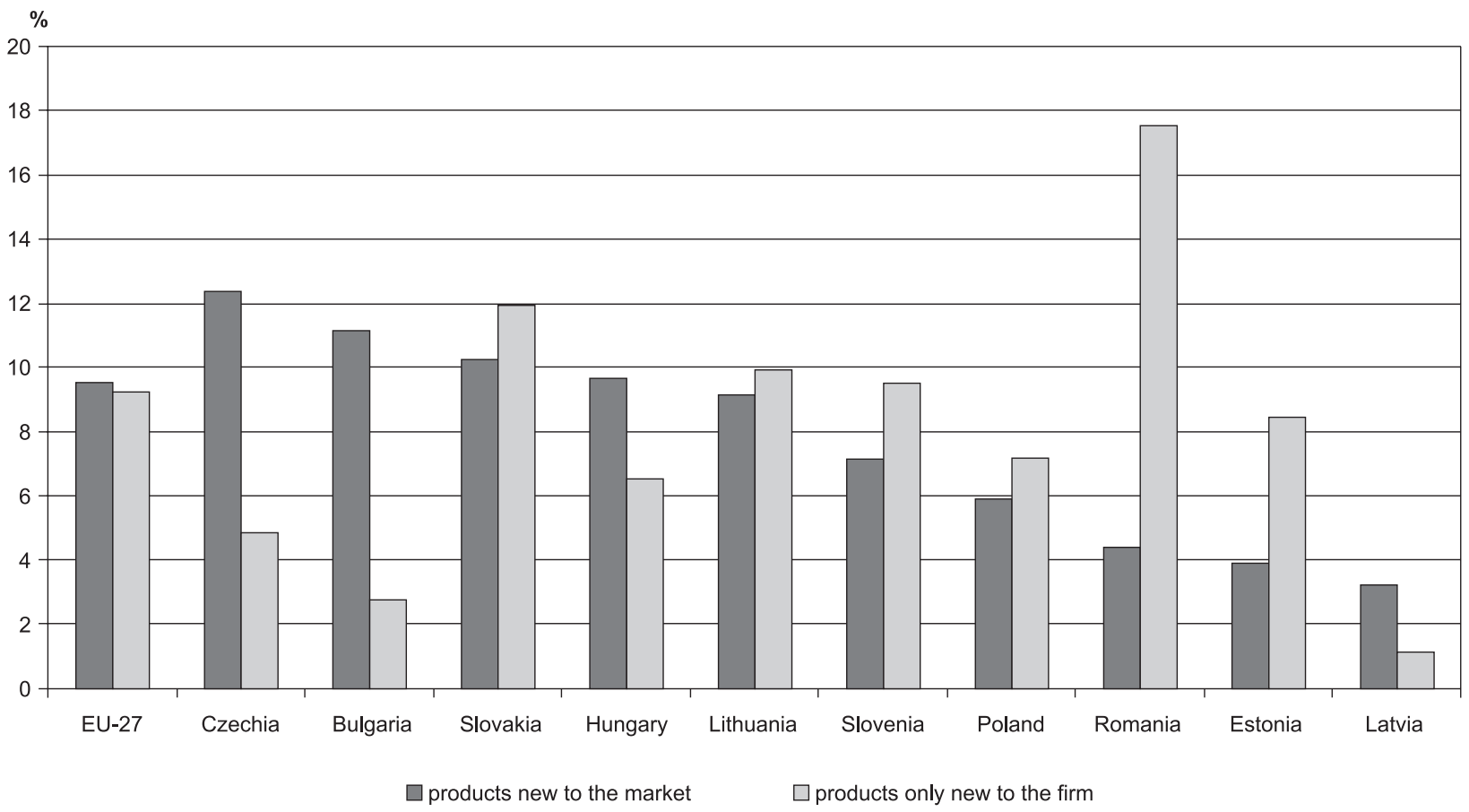

Fig. 5. Share of products new to the market and to a firm in the value of industrial production in Poland and other eastern EU states in 2000-2007.

Source: compiled by the authors on the basis of Eurostat data.

mechanisation, automation and computerisation. In the high-tech sector, the growing demand for labour, mostly highly skilled, was generated by R\&D departments, especially in companies with foreign capital. A supply of well educated graduates of higher technical schools is Poland's asset opening up perspectives of innovative thought development. A basic obstacle to making use of this potential is poor awareness of the need to develop cooperation between science and business. In 2008 there were only 1.6 publications per million inhabitants resulting from such cooperation, which is less than one-twentieth of the EU-27 average.

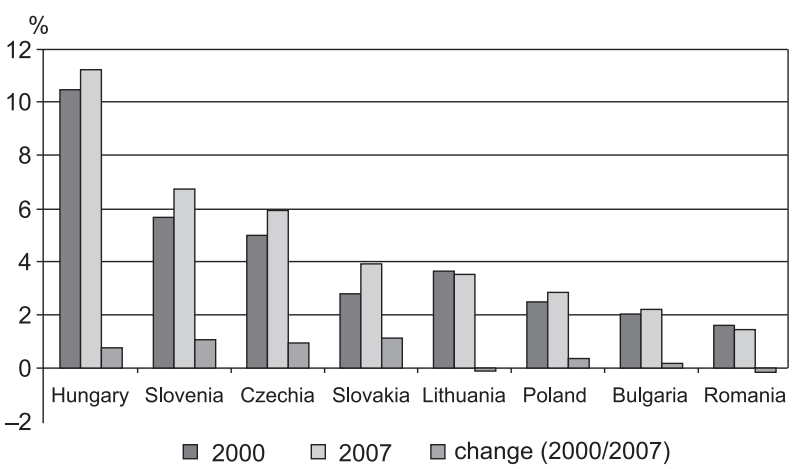

Fig. 6. Share of the high-tech sector in employment structure in Poland and other eastern EU states in 2000-2007. Source: compiled by the authors on the basis of Eurostat data.
It follows from the above analysis that the structural changes observed in the years 20002007 in Polish industry were very slow and took place mainly in sectors of lower technological advancement. An important question to answer is to what extent the modernisation of Polish industry is similar to that in the other EU states, especially those transforming their economies.

As in a previous study (Gierańczyk 2010b), an analysis was made of similarities in the modernity of industrial structures based on a synthetic indicator embracing four empirical measures, viz. the value of production, gross value added, profit, and employment. The method employed was cluster analysis (Ward's method). In both 2000 and 2007, four groups of states were distinguished in the EU. Poland fell into group four, with the lowest level of modernity in the entire study area, together with such CEE countries as Bulgaria, Romania and Lithuania, but also with Greece and Spain. During the study period the distance between the groups of states with the lowest and the highest levels of modernity increased, and in terms of states, that between Romania and Hungary, as well as between Poland and Hungary. In the last decade the high-tech sector in Hungary stood out for its much greater 
growth dynamics that industry in general, while in Poland high-tech branches developed at the same rate as total industry.

The persistent position of Poland in the group of states with the lowest level of modernity in the EU shows there to be limitations to the modernisation of industrial structures in this country. Numerous studies, e.g. by Stawasz, Głodek, Mizgajska, Wiszniewski, Platonoff, Miłaszewicz, or Sysko-Romańczuk (after Bieńkowska et al. 2007), indicate that these are predominantly financial obstacles. Limited possibilities of financing innovative activities from inner sources and barriers to acquiring capital from external sources determine decisions to upgrade machinery in the first place. In 2008 almost $90 \%$ of capital earmarked for innovations went to investment into fixed assets, mainly machines and equipment. The share of R\&D expenditure in the total amount of money spent on innovations remained low. Such a structure of capital devoted to innovativeness shows that firms strive to narrow the technological gap as fast as possible and with the use of outside material technology (Gaczek \& Stryjakiewicz 2008). A low share of the high-tech sector in industry has also roots in the low potential for R\&D in the Polish economy. Compared with other European Union members, including some CEE countries like Hungary or the Czech Republic, the potential for employment in R\&D in Poland and its share in employment is not significant, as demonstrated by numerous studies (e.g. Borowiec, Dorocki \& Jenner 2009; Lengyel \& Cadil 2009; Gierańczyk 2009a, 2010a, b; Rachwał 2009; Rachwał, Wiedermann \& Kilar 2009; Reinert, Kattel \& Suurna 2009).

\section{Conclusions}

The presented analysis of the changes in Poland's industry against the background of other eastern EU states in terms of modernity makes it possible to draw the following conclusions. First, in the researched period of time the share of industry in employment and gross value added shows a downward tendency both in Poland and most of the other states, although in some countries there is a slight upward tendency. With its small decrease in the share of industry over the years 1995-2007, Poland is still among the EU states with a high share of industry in the national economy. Secondly, changes in the structure of industry lead towards making it similar to that in the advanced EU states, which should be assessed as highly advantageous from the point of view of the goals of the economic transformation. Thirdly, compared with the other states, Poland has a relatively low share in employment and gross value added in highly advanced industrial sectors, which can be caused by unfavourable tendencies in employment and outlays for R\&D. As a result, at the time when the world enters an information phase of civilisational development and builds a knowledge-based economy, it is necessary for Polish authorities to make intensive efforts to create favourable conditions for a further structural transformation of the country's industry towards the production of technologically more advanced goods, which will allow Polish industry to improve its competitive position in international markets.

\section{References}

Bieńkowska A., Bojnowska A., WaleckA K. \& ZabŁockAKLUCZKA A., 2007. Bariery wewnętrzne działalności innowacyjnej w podmiotach na Dolnym Śląsku - wyniki badań (Internal barriers to innovation in Lower Silesian economic entities - research results). In: Strategie i doradztwo dla przedsiębiorstw. Teoria i praktyka. Oficyna Wyd.Reklamowa Hanna Wolska, Wrocław: 31-42.

Borowiec M., Dorocki S. \& JenNER B., 2009. Wpływ zasobów kapitału ludzkiego na kształtowanie społeczeństwa informacyjnego i innowacyjności struktur przemysłowych (Influence of human capital resources on the creation of information society and the innovativeness of industrial structures). In: Zioło Z. \& Rachwał T. (eds), Funkcje przemystu w ksztattowaniu społeczeństwa informacyjnego. Prace Komisji Geografii Przemysłu PTG, 13: 95-109.

Chojnicki Z. \& Czyż T., 2006. The role of knowledge in the shaping of a knowledge-based economy and economic development of Poland: A regional approach. Quaestiones Geographicae, 25: 7-15.

CZYŻ T., 2010. Competitiveness of the Wielkopolska region in terms of a knowledge-based economy. Quaestiones Geographicae, 29(2): 71-84.

DOMAŃSKI B., 2001. Kapitat zagraniczny w przemyśle Polski (Foreign capital in Polish industry). Instytut Geografii i Gospodarki Przestrzennej Uniwersytetu Jagiellońskiego, Kraków.

DOMAŃSKI B., 2003. Industrial change and foreign direct investment in the post-socialist economy: The case of Poland. European and Regional Studies, 10(2): 99-118.

DOMAŃSKI B., 2006. Polski przemysł na tle przemysłu Europy Środkowej i Wschodniej (Polish industry against that of 
Central and Eastern Europe). In: Zioło Z. \& Rachwał T. (eds), Międzynarodowe uwarunkowania rozwoju przemystu. Prace Komisji Geografii Przemysłu PTG, 8: 27-36.

FIC M., 2004. Analiza konkurencyjności sektorów tradycyjnych i sektora high-tech w województwie lubuskim (Analysis of the competitiveness of the traditional and high-tech sectors in Lubuskie voivodeship). In: Fic D. (ed.), Analiza wybranych obszarów konkurencyjności i innowacyjności w województwie lubuskim. Oficyna $\mathrm{Wy}$ dawnicza Uniwersytetu Zielonogórskiego, Zielona Góra: 127-171.

GaczeK W. \& Stryjakiewicz T., 2008. Innowacyjna Wielkopolska. Ocena realizacji celów Regionalnej Strategii Innowacji oraz stanu systemu innowacji w Wielkopolsce (Innovative Wielkopolska. Assessment of the objectives of the Regional Innovation Strategy achieved and of the innovation system in Wielkopolska). PPTN, Poznań.

GIERAŃCZYK W., 2003. Wybrane aspekty konkurencyjności polskiego przemysłu w dobie globalnych wyzwań rozwoju (Selected aspects of competitiveness of Polish industry in the age of global development challenges). In: Zioło Z. \& Makieła Z. (eds), Przemyst w procesie globalizacji. Prace Komisji Geografii Przemysłu PTG, 6: 77-86.

GIERAŃCZYK W., 2008. Handel zagraniczny wyrobami zaawansowanej technologii a społeczeństwo informacyjne Europy (Foreign trade in high-tech goods and the information society of Europe). In: Zioło Z. \& Borowiec M. (eds), Problematyka XXIV Międzynarodowej Konferencji Naukowej nt. Funkcje przemystu $i$ ustug w kształtowaniu społeczeństwa informacyjnego. Warszawa-Kraków: 22-23.

GIERAŃCZYK W., 2009a. Innowacyjność jako główny filar społeczeństwa informacyjnego Europy (Innovativeness as the main pillar of the information society of Europe). In: Zioło Z. \& Rachwał T. (eds), Funkcje przemystu w ksztattowaniu społeczeństwa informacyjnego. Prace Komisji Geografii Przemysłu PTG, 13: 82-94.

GIERAŃCZYK W., 2009b. Przemysł zaawansowanej technologii a konkurencyjność przemysłowa krajów UE (High-tech industry and the industrial competitiveness of the EU states). In: Zioło Z. \& Borowiec M. (eds), Problematyka XXV Międzynarodowej Konferencji Naukowej nt. Procesy transformacji przemystu $i$ ustug $w$ regionalnych $i$ krajowych układach przestrzennych. Warszawa-Kraków: 36-37.

GIERAŃCZYK W., 2010a. Innovativeness of the European Union against the leading world economies. Problems of Geography, 3-4: 40-47. Bulgarian Academy of Sciences, Sofia.

GIERAŃCZYK W., 2010b. Development of high technologies as an indicator of modern industry in the EU. Bulletin of Geography, 14: 23-36.

GRUDZEWSKI W. \& HejduK I., 2008. Zarządzanie technologiami. Zaawansowane technologie $i$ wyzwanie ich komercjalizacji (Management of technologies. Advanced technologies and the challenge of their commercialisation). Centrum Doradztwa i Informacji Difin sp. z o.o., Warszawa.

Gurbata M., 2010. Przemysł high-tech a poziom rozwoju społeczno-gospodarczego krajów (High-tech industry and the socio-economic development of countries). In: Zioło Z. \& Rachwał T. (eds), Procesy przemian przemystu $i$ ustug $w$ wybranych krajach/Processes of Transformation of Industry and Services in Selected Countries. Prace Komisji Geografii Przemysłu PTG, 6: 187-200.

LeNGyel B. \& CADIL V., 2009, Innovation policy challenges in transition countries: Foreign business R\&D in the Czech Republic and Hungary. Transition Studies Review, 16(1): 174-188.
Nauka i technika 2006 (Science and technology 2006), 2007. GUS, Warszawa.

OECD, 1996. The knowledge based economy. Paris.

RACHWAE T., 2006a, Efekty restrukturyzacji wybranych przedsiębiorstw przemysłowych Polski południowowschodniej (Effects of restructuring of selected industrial enterprises in south-east Poland). In: Zioło Z. \& Rachwał T. (eds), Efekty restrukturyzacji polskiej przestrzeni przemysłowej. Prace Komisji Geografii Przemysłu PTG, 9: 98-115.

Rachwaz T., 2006b. Restrukturyzacja technologiczna przedsiębiorstw przemysłowych Polski południowowschodniej jako czynnik podnoszenia ich konkurencyjności na rynku międzynarodowym (Technological restructuring of industrial enterprises of south-east Poland as a factor improving their competitiveness on the international market). In: Zioło Z. \& Rachwał T. (eds), Międzynarodowe uwarunkowania rozwoju przemystu. Prace Komisji Geografii Przemysłu PTG, 8: 192-203.

Rachwat T., 2008. Problematyka badawcza funkcjonowania przedsiębiorstw przemysłowych (Research problems concerning the operation of industrial enterprises). In: Zioło Z. \& Rachwał T. (eds), Problematyka badawcza geografii przemystu. Prace Komisji Geografii Przemysłu PTG, 11: 53-85.

Rachwat T., 2009. Changes of industry in the countries of Central and Eastern Europe under conditions of economic transformation and European integration. In: Kitowski J. (ed.), Countries of Central \& Eastern Europe versus global economic crisis. Geopolitical Studies, 15: 133-164.

RACHWAE T., 2010. Struktura przestrzenna i działowa przemysłu Polski na tle Unii Europejskiej w dwudziestolecie rozpoczęcia procesów transformacji systemowej (Spatial and branch structure of Polish industry as compared with the European Union after twenty years of systemic transformation processes). In: Zioło Z. \& Rachwał T. (eds), Procesy przemian przemystu i ustug w wybranych krajach/Processes of Transformation of Industry and Services in Selected Countries. Prace Komisji Geografii Przemysłu PTG, 16: 105-124.

RachwaE T., 2011a. Transformations of the employment structure as an expression of the transformation of the Polish industry against the background of the European Union. Bulletin of Geography, 15: 5-25.

Rachwat T., 2011b. Industrial restructuring in Poland and other European Union states in the era of economic globalization. Procedia. Social and Behavioral Sciences, 19: $1-10$.

Rachwat T. \& Wiedermann K., 2008. Multiplier effects in regional development: The case of the motor vehicle industry in Silesian voivodeship (Poland). Quaestiones Geographicae, 27B/1: 67-80.

RachwaE T., Wiedermann K. \& Kilar W., 2008. Wydajnośći koszty pracy jako czynniki konkurencyjności przemysłu regionów Polski w Unii Europejskiej w ujęciu regionalnym (Productivity and labour costs as competitiveness factors of the Polish regions in the European Union in a regional approach). In: Ilnicki D. \& Janc K. (eds), Przeksztatcenia regionalnych struktur funkcjonalno-przestrzennych "Europa bez granic - nowe wyzwania". Rozprawy Naukowe Instytutu Geografii i Rozwoju Regionalnego Uniwersytetu Wrocławskiego, 3: 79-89.

RachwaE T., Wiedermann K. \& Kilar W., 2009. Rola przemysłu w gospodarce układów regionalnych Unii Europejskiej (The role of industry in the economies of the Eu- 
ropean Union regional systems). In: Zioło Z. \& Rachwał T. (eds), Problemy ksztattowania się przestrzennych struktur przemystowych $i$ ich otoczenia. Prace Komisji Geografii Przemysłu PTG, 14: 31-42.

ReineRT E.S., Kattel R. \& SuURna M., 2009. Industrial restructuring and innovation policy in Central and Eastern Europe since 1990. Working Papers in Technology Governance and Economic Dynamics, 23. The Other Canon Foundation and Tallinn University of Technology, Tallinn.

Rot P. \& Brodzicki T., 2001. Przemyst wysokich technologii $w$ Polsce (High-tech industry in Poland). Raport Instytutu Badań nad Gospodarką Rynkową, Gdańsk.

SтAсношіAK K., 2009. Ewolucja przemysłu zaawansowanej technologii i sektora teleinformatycznego (ICT) w Finlandii (Evolution of high-tech industry and the ICT sector in Finland). In: Zioło Z. \& Rachwał T. (eds), Funkcje przemystu w ksztaltowaniu społeczeństwa informacyjnego. Prace Komisji Geografii Przemysłu PTG, 13: 122-132.

StAŃCZYK A., 2003. Społeczno-gospodarcze aspekty konkurencyjności Polski w warunkach globalizacji (Socio-economic aspects of the competitiveness of Poland in a global environment). In: Zioło Z. \& Makieła Z. (eds), Przemyst w procesie globalizacji. Prace Komisji Geografii Przemysłu PTG, 6: 87-100.

Stryjakiewicz T., 1999. Adaptacja przestrzenna przemystu w Polsce $w$ warunkach transformacji (The spatial adaptation of industry in Poland in the conditions of a transformation). Wydawnictwo Naukowe UAM, Poznań.

Stryjakiewicz T., 2002. Paths of industrial transformation in Poland and the role of knowledge-based industries. In: Hayter R. \& Le Heron R. (eds), Knowledge, industry and environment: Institutions and innovation in territorial perspective. Ashgate, Aldershot: 289-311.

StRYJAKIEWICZ T. (ed.), 2004. Wptyw inwestorów zagranicznych na rozwój regionalny i lokalny na przykładzie GlaxoSmithKline Pharmaceuticals S.A. w Poznaniu (Impact of foreign investors on regional and local development: The case of GlaxoSmithKline Pharmaceuticals S.A. in Poznań). Bogucki Wydawnictwo Naukowe, Poznań.

ŚwIDURSKA A., 2009. Kształtowanie się przemysłu wysokiej techniki w Polsce (Development of high-tech industry in Poland). In: Zioło Z. \& Rachwał T. (eds), Funkcje przemystu w ksztattowaniu społeczeństwa informacyjnego. Prace Komisji Geografii Przemysłu PTG, 13: 56-67.

ŚWIDURSKA A., 2010. Efektywność rozwoju przedsiębiorstw produkcyjnych wysokiej techniki w Polsce (Efficiency of development of high-tech manufacturers in Poland). In: Zioło Z. \& Rachwał T. (eds), Procesy transformacji przemystu $i$ ustug $w$ regionalnych $i$ krajowych uktadach przestrzennych. Prace Komisji Geografii Przemysłu PTG, 15: 197-208.

Thurow L.C., 1996. The future of capitalism. How today's economic forces shape tomorrow's world. N. Brealy Publishing, London.

ToвolsKa A., 2006a. Nowy model organizacji i funkcjonowania starych przedsiębiorstw przemysłowych (A new model of the organisation and operation of old industrial enterprises). In: Zioło Z. \& Rachwał T. (eds), Efekty restrukturyzacji polskiej przestrzeni przemystowej. Prace Komisji Geografii Przemysłu PTG, 9: 81-97.

ToвolsKa A., 2006b. Przestrzenne aspekty nowej organizacji i funkcjonowania przedsiębiorstw przemysłowych (Spatial aspects of the new organisation and operation of industrial enterprises). Przegląd Geograficzny, 78(4): 491-551.

ToвolsKa A., 2007. Bezpośrednie inwestycje zagraniczne a internacjonalizacja przemysłu polskiego (Direct foreign investment and the internationalisation of Polish industry). In: Lach J., Borowiec M. \& Rachwał T. (eds), Procesy transformacji społeczno-ekonomicznych i przyrodniczych struktur przestrzennych. Wydawnictwo Naukowe AP w Krakowie: $242-256$

TовоLSKa A., 2010. Miejsce inwestora zagranicznego w przestrzeni lokalnej i regionalnej na przykładzie Swedwood w Chlastawie (Place of a foreign investor in the local and regional space on the example of Swedwood in Chlastawa). Bogucki Wydawnictwo Naukowe, Poznań.

TUROWSKI K., 2005. Sektor wysokiej techniki jako główne źródło wzrostu we współczesnej gospodarce światowej (High-tech sector as the main source of growth in the contemporary global economy). In: Kopycińska D. (ed.), Funkcjonowanie gospodarki polskiej w warunkach integracji $i$ globalizacji. Uniwersytet Szczeciński, Szczecin: 269-278.

WiedermanN K., 2007. Regionalne efekty mnożnikowe rozwoju przemysłu motoryzacyjnego $\mathrm{w}$ aktywizacji gospodarczej województwa śląskiego (Regional multiplier effects of growth in the auto industry as an economic activator in Silesian voivodeship). In: Zioło Z. \& Rachwał T. (eds), Rola przedsiębiorczości w aktywizacji gospodarczej. Przedsiębiorczość-Edukacja, 3: 24-34.

WiśNIEWSKA J., 2002. Rola procesów dyfuzji rynkowej innowacji (The role of the processes of market diffusion of innovation). In: Modele, kapitat i miary efektywności przedsiębiorstw. Zeszyty Naukowe, 329, Prace Instytutu Ekonomiki i Organizacji Przedsiębiorstw, 40: 45-56.

ZALESKO E., 2008. Kapitał zagraniczny a innowacyjność przedsiębiorstw (Foreign capital and the innovativeness of enterprises). In: Kopycinska D. (ed.), Konkurencyjność podmiotów rynkowych. Katedra Mikroekonomii Uniwersytetu Szczecińskiego, Szczecin: 7-16.

ZıюŁo Z., 1972. Próba konstrukcji miernika syntetycznego w zastosowaniu do badań przemystu (An attempt to design a synthetic measure for use in the study of industry). Komisja Nauk Geograficznych. Sprawozdania z posiedzeń Komisji Naukowych PAN Oddział w Krakowie, XV/1: 191-194.

Zı૦Ło Z., 1973. Analiza struktury przestrzennej i form koncentracji przemysłu województwa rzeszowskiego w świetle wybranych mierników (Analysis of the spatial structure of industry and forms of its concentration in Rzeszów voivodeship in the light of selected indicators). Folia Geographica, VI: 95-116.

ZıঃŁo Z., 2008. Procesy transformacji przemysłowych układów przestrzennych na tle zmieniającego się otoczenia (Transformation of industrial spatial structures and the changing surroundings). In: Zioło Z. \& Rachwał T. (eds), Procesy transformacji układów przestrzennych przemystu na tle zmieniajacego sie otoczenia. Prace Komisji Geografii Przemysłu PTG, 10: 11-22.

Zı૦Ło Z., 2009. Rola przemysłu w procesie kształtowania społeczeństwa informacyjnego (Role of industry in the formation of an information society). In: Zioło Z. \& Rachwał T. (eds), Funkcje przemystu w kształtowaniu społeczeństwa informacyjnego. Prace Komisji Geografii Przemysłu PTG, 13: 11-20. 